KRZYSZTOF KWAŚNIEWICZ

\title{
MAUZOLEUM BL. SZYMONA Z LIPNICY Z KRAKOWSKIEGO KOŚCIOŁA BERNARDYNÓW
}

Pierwszy kościół św. Bernardyna na Stradomiu, u stóp wzgórza wawelskiego, powstał z fundacji braci Zbigniewa i Jana Oleśnickich po 1453 roku. Murowane i zasklepione miał tylko prezbiterium, reszta wykonana była z pruskiego muru i drewna. Budynek został rozebrany około roku 1600 , a na jego miejscu powstał większy, murowany, gotycki kościół $\mathrm{z}$ jedną wieżą ${ }^{1}$ Taką wersję historii budowli potwierdzają widoki Krakowa pochodzące $\mathrm{z}$ lat współczesnych; oba zamieszczone są w dziele Civitates orbis terrarum ${ }^{2}$. Poprzednie opracowane zostały $\mathrm{z}$ natury przez Idziego van der Rye przed 1600 rokiem (rytowany zapewne przez Jakuba Hoefnagla ${ }^{3}$ ). Drugi, autorstwa nieznanego rytownika powstał między rokiem 1603 a $1605^{4}$. Wcześniejszy ukazuje kościół Bernardynów bez charakterystycznej gotyckiej wieży z cebulastym hełmem ${ }^{5}$. Późniejszy, z początkowych lat XVII wieku, przedstawia go jako gotycką świątynię o wysokich dachach, z wysuniętą kruchtą (?) oraz wieżą przykrytą cebulastym hełmem, przylegająca do budynku od zachodu. Według katalogu zabytków kościół ten został przebudowany w latach $1645-1647^{6}$ i przetrwał aż do czasów potopu szwedzkiego, kiedy to na polecenie Stefana Czarnieckiego rozebrano go do fundamentów. Umiejscowiony w niedalekiej odległości od murów zamkowych, w razie opanowania przez nieprzyjaciela, stanowić mógł poważne zagrożenie. Jednak źródła ikonograficzne (rysunek pochodzący z okresu oblężenia w 1655 r. wykonany przez Czecha w służbie szwedzkiej,

${ }^{1}$ Cz. B o g d a ls k i, Blogostawiony Szymon z Lipnicy. Jego życie i cześć pośmiertna. Kraków 1909.

2 J. B ra u n, F. H o e f $\mathrm{n}$ a g e 1 , Civitates orbis terrarum, t. 6, Theatri praecipuarum totius mundi urbium liber sextus, Kolonia 1617, tabl. 44.

${ }^{3}$ J. B a n a c h, Dawne widoki Krakowa, Kraków 1983, s. 179.

${ }^{4} \mathrm{~J}$. B r a u n, F. H o e fn a g e 1, Civitates orbis terrarum..., tabl. 43, zob. też J. B a n a c h, Dawne widoki..., s. 179-180.

${ }^{5}$ Widoczne jest to zarówno wtedy, gdy uwzględnić interpretację J. Banacha (dz.cyt. s. 55) jak i drugą możliwą przyjmująca że kościół bernardynów to najbardziej wysunięta na południowy wschód budowla przylegająca do murów wawelskich.

${ }^{6}$ Katalog zabytków sztuki w Polsce, t. 4, Miasto Kraków, cz. 4 Kazimierz i Stradom, s. 10 i ns. 
Macieja Palbitzkiego) ukazują świątynię stojącą w momencie oblężenia ${ }^{7}$. Trzeci kościóit, któny istnieje do dniã dzisiejszego, zbudowany został w latach $1659-1680^{8}$, w stylu barokowym.

$\mathrm{Z}$ historią kościoła nierozerwalnie związane są dzieje nagrobka bł. Szymona z Lipnicy 9 . Pomimo jego próśb, by pochować go pod progiem, ciało jego złożono pod chórem zakonnym pomiędzy Tymoteuszem z Sylwano, magistrem sztuk, a bratem Bernardynem z Żarnowca - kantorem ${ }^{10}$. Jednak na skutek nasilającego się kultu gromadzący się ludzie nie mogli pomieścić się w chórze pierwszego kościoła. Po uzyskaniu zgody Stolicy Apostolskiej dokonano w 1488 roku podniesienia szczątków Szymona i umieszczono je w przygotowanym grobowcu w prezbiterium. Na początku wieku XVII powstał nowy kościół, w którym grobowiec błogosławionego znajdował się w kaplicy św. Anny ${ }^{11}$. Stan taki nie trwał jednak długo. Po około 50. latach, wobec zagrożenia szwedzkiego, przeniesiono relikwie Szymona z Lipnicy do jednej z kaplic katedry wawelskiej, a kościół został zburzony. W trzeciej świątyni powstała kaplica - mauzoleum. Szczątki błogosławionego zostają przeniesione $\mathrm{z}$ powrotem do bernardyńskiego kościoła dopiero 15 maja 1686 roku, do kaplicy odnowionej na koszt Jana Lipskiego, który też był fundatorem oltarza $\mathrm{i}$ grobowca ${ }^{12}$. Od tego czasu relikwie pozostają w tym miejscu, a kaplica - z pewnymi zmianami - przetrwała do dzisiejszego dnia.

${ }^{7}$ M. Palbitzki, Wawel i Kraków z okna Augustianów na Kazimierzu, 1655, [w:] J. $\mathrm{B}$ a n a c h, Dawne widoki..., s. 87.

${ }^{8}$ Następne restauracje prowadzone w latach $1755,1765,1860-1861,1867-1869,1895$, 1921-1930,1967-1969. Katalog zabytków..., s. 10 n.

${ }^{9}$ Urodzony około roku 1438-1440 nauki pobieral w Akademii Krakowskiej. W 1457 uzyskał tu stopień bakałarza i niedługo później, razem z dziesięcioma kolegami wstapił do założonego przez Jana Kapistrana krakowskiego klasztoru obserwantów, zwanych od wezwania kościoła - św. Bernardyna ze Sieny - bernardynami. Przed 1465 rokiem uzyskał święcenia kapłańskie i został przełożonym konwentu tarnowskiego. Następnie był kaznodzieją przy klasztorze na Stradomiu. Był obecny w 1472 w Akwili na uroczystości przeniesienia ciała św. Bernardyna ze Sieny; potem wysłano go jako delegata na kapitułę ogólnozakonną do Pawii, po jej zakończeniu odbyl pielgrzymkę do Rzymu, a później do Ziemi Świętej. Następnie pełnił różne funkcje w zakonie (miał być według tradycji mistrzem nowicjatu). W 1482 wybrano go delegatem na kapitułe prowincjonalną w Kole. Zanim jednak do niej doszło Szymon zmarł podczas trwającej w tym czasie w Krakowie epidemii, 18 lipca 1482 roku. - H. F r o s SI, F. S o w a, Twoje imię. Przewodnik onomastyczno-hagiograficzny. Kraków 1995, s. 194.

${ }^{10} \mathrm{P}$. H. P ru s z c z, Przewodnik, abo kościołów krakowskich $i$ rzeczy $w$ nich widzenia godnych krótkie opisanie. Naprzod tych co sq na Kazimierzu y Stradomiu... Kraków 1603. Przedruk staraniem J. Łe p k o w s k i e g o, Kraków 1860 jako Kościołów krakowskich opisanie..., s. 121 oraz O. Norbert G o 1 i c h ow s k i, Bt. Szymon z Lipnicy. Żywot, Pamiątki i Nabożeństwo. Kraków 1898, s. 15.

${ }_{11}$ "1686 r. dnia 15 maja w uroczystej procesyi wniesiono napowrót z Wawelu do własnego kościoła na Stradomiu święte relikwie Jego i złożono w marmurowym grobowcu, czyli na ołtarzu w kaplicy od strony północnej kościoła zbudowanej" (Przedtem, jak z opisów podczas procesów kanonicznych wypływa, grobowiec Bł. Szymona znajdował się. w kaplicy św. Anny. [Notatki z procesu kanonicznego w r. 1641, oraz książki O. Adama Miecznikowskiego]), N. Gol i c how s k i, Bt. Szymon ..., s. 20.

${ }_{12}$ Według katalogu miała ta budowa nastapić 1662, Norbert Golichowski podaje rok 1677. - N. Go li c how sk i, Bt. Szymon ..., s. 20). 
Znajduje się ona u szczytu północnej nawy bocznej kościoła. Pierwotnie od reszty wnętrza odgradzała ją krata ${ }^{13}$ obecnie - wydzielona jest balustradą o formach barokowych. W centrum znajduje się pomnik Szymona z Lipnicy stanowiący pierwotnie część ołtarza. Na mensie ustawiony jest sarkofag $\mathrm{z}$ posagiem błogosławionego wykonany $\mathrm{z}$ marmuru paczułtowickiego(?) ${ }^{14}$, którego ciepła, rudobrązowa barwa wspaniale kontrastuje z czernią marmuru dębnickiego pozostałych części nagrobka. Szymon z Lipnicy przedstawiony jest w pozycji leżącej na wznak, z głową wspartą na poduszce i złożonymi na piersiach rękami ${ }^{15}$. Ubrana $w$ franciszkański habit postać spoczywa „uśpiona w Bogu", jak to określił N. Golichowski. Kaptur habitu do połowy nasunięty jest na głowę, sznur przepasujący błogosławionego w talii jest niewidoczny skryty pod rękawami habitu, widać tylko jego luźny koniec ułożony pomiędzy nogami i sięgający aż do stóp; znajdują się na nim trzy węzły. Frontową część mensy zdobi antepedium $z$ czarnego marmuru wykonane przez Jacka Zielaskiego (sygnowane JZF). Antepedium dekorowane jest płaskim, polerowanym ornamentem naśladującym tkaninę o wzorach floralnych. Obramowane jest wąską bordiura, również zdobioną roślinnym ornamentem. Środek antepedium podzielony jest na pięć pól pasami o ornamencie arabeskowym; w środkowym znajduje się owalny medalion zawierający herb fundatorów - Śreniawa oraz ich inicjały J(an) L(ipski) Z(ofia) L(ipska) S(ądecki) Ch (Czchowski) S(tarosta). Na dole medalionu, umieszczona jest sygnatura wykonawcy $J(a c e k)$ $\mathrm{Z}$ (ielaski) $\mathrm{F}$ (ecit). W dwóch trzecich wysokości przebiega pas naśladujący frędzle tkaniny.

Zarówno mensa jak i sarkofag zostały przesunięte $\mathrm{z}$ pierwotnego miejsca - oltarza - do centrum kaplicy, widoczne są ślady sztukowania brakujacych części - około jednej trzeciej głębokości tak mensy jak i sarkofagu ${ }^{16}$. Również rzeźba znajdująca się na sarkofagu posiada ślady reperacji ${ }^{17}$, przy czym część uzupełnionych elementów od strony przylegającej kiedyś do retabulum odpadła. Uszkodzona była lewa część figury: dorobione zostały: cała

${ }^{13}$ Wymienia ją jeszcze o. Norbert Golichowski w 1898. - N. Go li ch ow s k i, Bt. Szymon..., s. 20.

${ }^{14}$ Katalog zabytków..., s. $10 \mathrm{i}$ nn; prawdopodobnie jest to tzw. marmur chęciński lub może marmur węgierski.

${ }^{15}$ Rzeźba przeznaczona jest do oglądania $\mathrm{z}$ boku; tylko taka pozycja obserwatora pozwala na prawidłowy wygląd skrzyżowanych rąk błogosławionego; zdjęcia z góry pokazuja, że ułożenie rąk takie jak zostało pokazane na nagrobku jest niemożliwe $\mathrm{z}$ anatomicznego punktu widzenia.

${ }^{16}$ Zachowała się $\mathrm{w}$ archiwum dokumentacja tych dzialań, która pozwala określić zakres zmian: mensa wraz ze znajdującym się na niej sarkofagiem przykrytym figurą Szymona została wysunięta na środek kaplicy, dosztukowano brakujące części tak mensy jak i sarkofagu, wykonano nowe podstawy sarkofagu a takze wyłożono powierzchnię mensy płytami z czarnego marmuru. Frontową część jak dawniej stanowi antepedium autorstwa Zielaskiego. Przy ołtarzu na miejscu przesuniętej mensy umieszczono płytę z inskrypcja.

${ }^{17}$ Przywoływana wyżej dokumentacja nie zawiera informacji dotyczących napraw rzeźby. Nie były zdaje się przeprowadzane - co potwierdzają istniejące ubytki. Jedyna dostępna informacja o naprawach rzeźby znajduje się w kontrakcie z Marcinem Krystianem (patrz aneks) i pochodzi z 1662 roku. 
lewa część poduszki, lewa strona kaptura habitu, fragment lewego ramienia, cała lewa krawęúz habitu aź do stóp, przy czym brak części właśnie tego fragmentu rekonstrukcji. Przez przeszklony otwór znajdujący się w mensie od strony ołtarza można ujrzeć relikwiarz ze szczątkami zmarłego. W tym też miejscu przechowywany jest brakujący fragment rzeźby.

Ołtarz znajdujący się w kaplicy ma retabulum w formie aedikuli z płytką arkadą utworzoną przez dwa zdobione po zewnętrznych stronach wolutami pilastry, na których wspiera się przerwany w środku przyczółek o wystającym gzymsie. W jego środku, w medalionie otoczonym wolutami umieszczony jest herb Śreniawa. Całość wykuta jest $\mathrm{z}$ czarnego, dębnickiego marmuru, $\mathrm{z}$ pewnymi elementami - np. klucz archiwolty, kapitele, bazy - wykonanymi z marmuru brunatnego. Jego autorstwo przypisywane jest - mylnie - Marcinowi Krystianowi z Kazimierza ${ }^{18}$.

Umieszczony w ołtarzu obraz namalowany został przez Jana Gotharda Berkhoffa ${ }^{19}$ z Wilna w 1685 roku. Przedstawia on sceny z legendy o bł. Szymonie. Na pierwszym planie Szymon z księgą wskazuje ręką na posłusznego nowicjusza wstępującego na rozżarzone węgle; $\mathrm{z}$ tyłu przyglądają się inni. $\mathrm{Z}$ góry, po lewej stronie w sferze niebiańskiej znajduje się Madonna z dzieciątkiem w otoczeniu aniołków obserwująca zdarzenie. Po prawej stronie obrazu, na dalszych planach, kolejne sceny z żywota św. Szymona (w kolejności planów, od najbliższego): sadzenie kwiatów; sadzenie dębu; studnia bł. Szymona oraz - w tle - kościół bernardynów widziany od prezbiterium. Obraz ozdobiony był w 1746 roku srebrną sukienka, lecz została ona skradziona ${ }^{20}$.

Kaplica wyposażona kiedyś była w wieczną lampę fundacji Kazimierza Sadowskiego ${ }^{21}$; lampa ta widoczna jest jeszcze na zdjęciach $\mathrm{z}$ początku XX wieku.

Wygląd pierwotnego pomnika Szymona z Lipnicy jest znany tylko z przekazów, pochodzących z początków XVII wieku ${ }^{22}$. Szymon Starowolski

${ }^{18}$ Taką informację podaje zarówno Katalog zabytków..., jak i np. Tadeusz D o b r o wolski w Sztuce Krakowa (Kraków 1950) oraz Tadeusz M a ń k ow sk i, Bernardyńskie pomniki grobowe, Prace Komisji Historii Sztuki IX, 1948, s. 197, Jan S a m e k, Nawrót do gotyku w sztuce Krakowa Pierwszej połowy w. XVII, „Folia Historiae Artium”, t. 5:1968, s. 100, czy Joanna D a ra now s k a - Ł u k a s z ew sk a, Sposób pochówku a forma niektórych nagrobków nowożytnych w Polsce, „Studia Muzealne” z. 19:2000, s. 72-78.

${ }^{19}$ Jan Gothard Berkhoffa (Berchhoff, Berghof) z Wilna był malarzem pochodzenia niemieckiego, tworzącym w 2 poł. XVII w. na Litwie. Prócz obrazu dla bernardynów krakowskich znane są jego obrazy znajdujące się w katedrze wileńskiej, w kaplicy Marii Magdaleny. Zob. Stownik Artystów Polskich, t. 1, Wrocław-Warszawa 1971, s. 134.

${ }^{20}$ C. B o g d a 1 s k i, Blogostawiony Szymon..., s. 128-129.

${ }^{21}$ Tamże, s. 125.

${ }^{22}$ Wizerunek doskonatości apostolskiej, albo żywot bt. Szymona z Lipnice, z przydatkiem różnych łask, których u grobu Jego ludzie doznaja. Zakonu Braci Mniejszych Oyca S. Franciszka OO Bernardynów. Wielkiego Cudotwórce, który tak za żywota jako y po śmierci stynafl] $i$ dotąd cudami stynie. Kraków 31735 (wyd. I - Kraków 1609, wyd. II - Kraków 1703) s. 22-23, oraz Adam M i e c z n i k ow s ki Vita beati Simoni, Kraków 1611, s. 26, a także źródła rękopiśmienne, zob. niżej oraz aneks. 
zanotował w swoim dziele Monumenta Sarmatarum... treść inskrypcji mauzoleum, w ten sposób dotrwała ona do dzis ${ }^{23}$.

Wszystkie opisy tego nagrobka wymieniają figurę przedstawiającą błogosławionego, znajdująca się na grobowcu. Potwierdza to zarówno anonimowy Wizerunek doskonatości apostolskiej, albo żywot bt. Szymona z Lipnice... jak i późniejsze opracowania. Opisy mówią o marmurowej statui przedstawiającej zmarłego:

„Był na ten czas papieżem Innocentiusz VIII. Namiestnik Chrystusów, który powziąwszy wiadomość o niewinności żywota i rozlicznych cudach, które Pan Bóg u grobu Błogosławionego Szymona czynić raczył, pozwolił ciało jego $\mathrm{z}$ grobu podnieść i do wielkiego Chóru w Kościele tymże uczciwie przenieść. Otrzymawszy tedy Diploma Ojcowie Bernardyni od Stolice Apostolskiej, z wielką radości i z jaką mogli największą uczciwością przenieśli przy frekwencyi wielu ludzi, tak Duchownego jak i świeckiego stanu, ono ciało święte. Złożyli tedy on drogi Skarb y statue marmurowa tegoż Osoby wizerunek nad ciałem jego Świętym położyli, ${ }^{24}$.

„Y połozyli go ucciwie po lewey stronie w kosciele iako teraz yest. A na grobie iego osobe z kamienia wyrzezana położyli ${ }^{25}$.

„Wtedy to [12 sierpnia 1488] przy zamkniętych drzwiach kościelnych a w obecności samych tylko zakonników otworzono grób Szymona z Lipnicy. Ze czcią zebrano święte reszty [...] i przeniesiono do wcale okazałego grobowca $\mathrm{z}$ kamienia, umieszczonego przy bocznej ścianie tuż przed wielkim ołtarzem. W przygotowanym wydrążeniu grobowca złożoną została skrzynka czyli trumienka z relikwiami, poczem zakryto wydrążenie ogromną płytą marmurowa na którei w wielkości naturalnei a pozycvi leżacei wykuta została uderzaiaco podobna postać Szvmona z Lipnicy.

[...] Sarkofag [do którego przeniesiono relikwie po beatyfikacji - K.K.] zamknięty jest $\mathrm{z}$ wierzchu wielką płytą $\mathrm{z}$ marmuru czerwonego, w której wykuta jest w naturalnej wielkości leżąca postać świętego męża. Według bardzo starej tradycji, - gdyż płyta z postacia pochodzi ieszcze z pierwotnego grobowca, - oblicze wykute w marmurze ma przedstawiać wiele rysów podobieństwa do bł. Szymona za jego życia"26.

Ad Opt: \& Max: DEI Laudem \& Gloriam.

Mausoleum istud dedicatum est B. Simoni de Lipnica.

Viro utique ante omnia in Ordine Minorum Religiosissimo Sanctissimoque,

Deinde Viro augustissimi Nominis Iesu Praedicatori feruentissimo.

Tum vitae sanctimonia, ac praecipe virginali castimonia, integerrimo,

Admirandum denique, ac paene innumerabilium prodigiorum,

Singulari praerogative longa lateque clarissimo.

Migravit e vita Anno Domini, M.CCCC.LXXXII.

-S. S t a r o w o $1 \mathrm{~s} \mathrm{k} \mathrm{i,} \mathrm{Monumenta} \mathrm{Sarmatarum} \mathrm{viam} \mathrm{universae} \mathrm{carnis} \mathrm{ingressorum,} \mathrm{Cracoviae}$ 1655 , s. 165 .

${ }^{24}$ Wizerunek doskonatości apostolskiej..., s. 22-23.

${ }^{25}$ A. M i e c z n i k o w s k i, Vita beati Simonis, Kraków 1611, s. 26.

${ }^{26}$ C. B o g d a 1 s k i , Btogostawiony Szymon ..., s. 128-129. 
„Trumna marmurowa z postacią Sługi Bożego pochodzi z pierwotnego ieszcze gotyckiego kościółka przed spaleniem.,27

Jak już wspomniano obecnie istniejący ołtarz przypisywany jest Marcinowi Krystianowi, jednak zachowany kontrakt $\mathrm{z}$ roku $1662^{28}$ opisuje znacznie różniący się od dzisiejszego;

,[...] w Tumbie ma bydz persona Błogosławionego Szymona z marmuru wiśniowego koloru, $[\ldots]$ columny maią bydz na cztery łokcie bez ćwierci marmurowe, capitele zas pstrego marmuru, albo alabastrowe, ieżeli bedzie mogło bydz, pyramydy czarnego marmuru, ozdobione drobno dla wydatnosci alabastrem, szpregle czerwonego marmuru, structura wszystkiey roboty nagrobku marmurowego wzwysz rachuiąc y z Tumbą na dziesięc łokci..."29.

Nie ma ani słowa na temat obrazu, stanowiącego dzisiaj integralną część ołtarza (powstał, jak już wyżej wspomniano w 1685 roku). Prawdopodobnym wydaje się twierdzenie, że obecny wygląd ołtarza (pomijając wysunięcie mensy wraz figurą na środek kaplicy, co miało miejsce w 1946 roku) związany jest $\mathrm{z}$ remontem i przeróbkami związanymi z powtórnym przeniesieniem relikwii błogosławionego (1686). Powstaje wtedy wspominane już antepedium fundacji Lipskich, również ołtarz ma być jego fundacji (według kontraktu fundatorem nagrobka wykonanego przez Marcina Krystiana jest zgromadzenie ${ }^{30}$ ).

Wobec przywołanych źródeł przyjmowane do tej pory datowanie przestaje być aktualne. Potwierdza to również problem autorstwa figury błogosławionego. Do tej pory, powołując się na kontrakt z Marcinem Krystianem wskazywano na rok 1662 jako moment powstania figury Szymona z Lipnicy. Jednak przywoływane już źródła mówią o istniejącej wcześniej rzeźbie (od momentu podniesienia relikwii - czyli od 1488 roku). Sam kontrakt - co nie zostało do tej pory zauważone - wyraźnie mówi o wykorzystaniu już istniejącej figury do konstrukcji nagrobka:

„W Tumbie ma bydz persona Błogosławionego Szymona z marmuru wiśniowego koloru, ktory iest na Stradomiu, wypolerowawszy co potrzeba, to co iest zepsowanego"31.

Tak więc przedstawienie Szymona na pewno jest starsze od istniejącego nagrobka, a także tego, który wykonywał Marcin Krystian w 1662 roku.

Najwcześniejsza wzmianka archiwalna, pomijając już przytoczone, pochodzi $\mathrm{z}$ akt procesu beatyfikacyjnego, z 1637 roku. Figura wzmiankowana tam jest jako istniejąca w 1607 roku, kiedy to oglądał ją Adrian Grymza. ( $\underline{F r}$

${ }^{27}$ O. Fidelis K ęd zi ierski, O Btogostawionym Szymonie z Lipnicy. Myśli i Refleksje powstate z okazji uroczystego przeniesienia swiętych relikwii bt. Szymona z Lipnicy do odnowionej kaplicy - grobu Stugi Bożego przy kościele OO. Bernardynów na Stradomiu w Krakowie (17 do 21 lipca 1946). Kraków 1946. s. 31.

${ }^{28}$ Archiw. Prow. Bernardynów w Krakowie (dalej: APBK) rkp. I-e-7: Akta dotyczace Błogosławionego Szymona z Lipnicy i jego kultu 1486-1949, s. 39-42.

${ }^{29}$ Por. aneks; Łokieć polski w 1651 mierzył około $57,5 \mathrm{~cm}$; był to znormalizowany łokieć warszawski potwierdzony w XVIII w. przez Komisję Skarbową Koronną. - Z. G lo g e r, Encyklopedia Staropolska, t. 3, Warszawa 1972, s. 163.

${ }^{30}$ Zob. aneks.

${ }^{31}$ Zob. aneks. 
Simon de Lipnica Bernardyn ktorego osobe z Kamienia wyrzezana na Stradomiu w Kościele u Ovcow Bernardynow widvwał $)^{32}$. Tenże gdy prosił w chorobie o wstawiennictwo Szymona zaraz został uzdrowiony i śluby dziękczynne uczynił. Ufundował nagrobek Szymonowi, przeznaczając na ten cel sześćset złotych. Miał ten fakt potwierdzić w rozmowie z Radziechowskim w 1609 roku, a Radziechowski podczas zeznań do procesu, beatyfikacyjnego, w 1637 roku ową rozmowę powtórzył:

„Anno 1609. prawdziwie przyznał y pod przysięga powiedział. Ukazał mi się S. Szymon z Lipnice y obiecał mi zdrowie bom iuz od Doktorow odstąpiony był; ia natychmiast ozdrowiał $\mathrm{v}$ in gratitudinem huic Sancto Patrono meo, mausoleum extruxi."

Tradycję wczesnego pochodzenia figury bł. Szymona przywołuje też wzmianka „Ex libro antiquo scripto Conventu Samboriensi: De situ fundatione ac divisione provinciae. De beato Fr[atr]e Simone Lipnico Cracoviae in Ecclesia Fr[atr]um Minorum ad Sanctum Bernardinum tumulato", gdzie można przeczytać: „Ad sinistram partem translat[us] et in monumento de lapido erecto cum exsculpta de illo toti[us] corporis effigia condit[us] est ${ }^{\prime 34}$.

Gdyby przywołana tradycja o faktycznym wizerunku błogosławionego okazała się prawdziwą należałoby przesunąc datę powstania rzeźby na koniec wieku XV(?). To mało prawdopodobne, choć w tym okresie istniały już wawelskie nagrobki Kazimierza Wielkiego czy Władysława Jagiełły, wykorzystujące podobny schemat: leżącej na wznak postaci umieszczonej na tumbie. Gdy dodać do tego informację, że nagrobek Jagiełły nie posiadał początkowo baldachimu (który został ufundowany dopiero przez Zygmunta Starego) podobieństwo ukaże się wyraźniej. Także i później powstawały w Krakowie nagrobki wykorzystujące powyższy schemat: istniał w Krakowie w latach 1581-1583 niezachowany nagrobek św. Jacka Odroważa w kościele dominikanów, a którego przechowane do dziś opisy, mówią o figurze świętego naturalnej wielkości, w pozycji leżącej, znajdującej się na sarkofagu ${ }^{35}$.

Badacze zaliczaja mauzoleum bł. Szymona do grupy tzw. nagrobków bernardyńskich ${ }^{36}$ razem z pomnikiem św. Jana z Dukli (Lwów 1608) i bł. Rafała z Proszowic (Warta 1640) oraz bł. Michała Giedroycia (Kraków I ćw. XVII w.).

${ }^{32}$ APBK rkp. sygn. I-e-2: Akta dotyczące procesu beatyfiakcyjnego Błog. Szymona z Lipnicy, 1637 rok, s. 75.

${ }^{33}$ Patrz aneks; APBK Rkp. sygn. I-e-2: Akta dotyczące procesu beatyfiakcyjnego Błog. Szymona z Lipnicy, 1637 rok, s. 75-76 a także 64, 69, 77.

${ }^{34}$ APBK Rkp. sygn. I-e-2: Akta dotyczące procesu beatyfikacyjnego Błog. Szymona z Lipnicy, 1637 rok, s. 139.

${ }^{35} \mathrm{~K}$. S in k o-P o p i e l o w a, Zaginiony nagrobek św. Jacka w Krakowie, Prace Komisji Historii Sztuki IX, 1948, s. 65-86; S. Ś w i s z c z e w s k i, Rekonstrukcja nagrobka św. Jacka, Prace Komisji Historii Sztuki IX, 1948, s. 86-87; J. S a m e k, Nawrót do gotyku, s. 101.

${ }^{36}$ T. M a ń k o w s ki i, Bernardyńskie pomniki..., s. 197; T. Do b row o 1 s k i, Sztuka Krakowa, Kraków 1950; J. S a m e k, Nawrót do gotyku..., s. 100. T. D o b r o w o l s k i zalicza do nich także nagrobny posag biskupa Andrzeja Lipskiego z katedry wawelskiej oraz zachowany w kościele Bożego Ciała nagrobek bł. Stanisława Kazimierczyka (Sztuka Krakowa, s. 346). 
Gdyby przyjąć proponowaną teorię o wieku rzeźby stała by się ona wzorem ủla pozostałych nagrobków tego zespołu. W zestawieniu $\mathrm{z}$ pozostałymi pomnikami „bernardyńskimi” uderza znacznie swobodniejsze potraktowanie postaci, bardziej miękkie krawędzie a także mniej sztywna poza. W wypadku pomników z Warty i Lwowa można by chyba mówić o pewnych cechach gotycyzujących (,sztywność" i pewna schematyczność sylwetki, ostre potraktowanie fałd, przedstawienia ukazują raczej wyidealizowanego świętego niż konkretną osobę) podczas gdy w wypadku Szymona z Lipnicy wyraźne są cechy portretowe, artysta także wiernie odtworzył wydęty brzuch błogosławionego. Pogłębia to wrażenie również fakt, że zarówno w nagrobku św. Jana z Dukli jak i bł. Rafała z Proszowic rolę podgłówka pełni księga, podczas gdy na nagrobku Szymona $z$ Lipnicy jest to poduszka, podobnie jak w wypadku nagrobka bł. Michała Giedroycia (datowanego na I ćwierć XVII wieku) z kościoła św. Marka w Krakowie.

Wobec przedstawionych informacji uprawnionym więc wydaje się stwierdzenie, że rzeźba $\mathrm{z}$ krakowskiego kościoła bernardynów powstała najpóźniej na początku wieku XVII, a być może jeszcze wcześniej. Cechy stylistyczne rzeźby pozwalają szukać pokrewnych jej na początku wieku XVII. Mowa tu o nagrobku Jadwigi z Włodków Firlejowej, znajdującym się w kościele franciszkanów w Krośnie. Nagrobek ten, datowany na 1611, projektu Lucano Reitino de Lugano Italiano ${ }^{37}$ zawiera w sobie rzeźbę zmarłej, w pozycji leżącej na wznak. Pomijając inny układ rąk i większą strojność ubioru rzeźba jest bardzo podobna w układzie ciała i sposobie ekspozycji. Tak jak rzeźba Szymona przeznaczona jest do oglądania z boku, w związku z tym występują te same nieprawidłowości anatomiczne w wykonaniu rąk. Również lekko pochyłe (w stronę patrzącego) ułożenie sylwetki Szymona zdaje się potwierdzać podobieństwo. Różnicę stanowi fakt, że w pomniku Firlejowej figura stanowi całość z płytą na której leży. Figura Szymona jest samodzielna, jednak niewykluczone, że została odcięta od podstawy w toku przeróbek, które potwierdzone są archiwaliami. Tym bardziej, że rzeźba nosi ślady reperacji, uzupełnień $\mathrm{i}$ - może właśnie - przeróbek.

Problemem niewyjaśnionym pozostaje autorstwo rzeźby Firlejowej. O ile caly nagrobek jest projektu Reitino, o tyle co do rzeźby istnieja obiek$\mathrm{cje}^{38}$. Natomiast wart zauważenia wydaje się fakt powiązania Lugańczyka z zakonem franciszkańskim. Jego prace znajdują się w Krakowie, w kościele św. Franciszka - portale, a także prawdopodobnie pomnik Jana Gemmy - oraz w Krośnie, również w kościele franciszkanów (wspominany pomnik Firlejo-

${ }^{37}$ Lucano Reitino de Lugano Italiano murarz krakowski, pracował na zamku wawelskim jako pomocnik G. Trevano. Szerzej na ten temat pisali: Stanisław o z a, Architekci i budowniczowie w Polsce, Warszawa 1954, s. 256; M. Ka rpowicz, Artisti Ticinesi in Polonia nel'600, Republica e Cantone del Ticino 1983, s. 38 n.; Tenże, Kilka uwag o autorze nagrobka Firlejowej w kościele Franciszkanów w Krośnie, [w:] Kościót i klasztor franciszkański w Krośnie, przeszłość oraz dziedzictwo kulturowe. Materiały z sesji naukowej, Krosno, listopad 1997, Krosno 1998, s. 169-177.

${ }^{38}$ Tamże, s. $173 \mathrm{n}$. 
wej). Stradomski pomnik Szymona z Lipnicy również znajduje się w kościele franciszkańskim (bernardyni to też franciszkanie).

Czy obecna forma pomnika Szymona jest przetworzonym projektem Reitino jest dyskusyjne, można by się jednak pokusić o analizę porównawcza. Zarówno przerwane przyczółki, tablice inskrypcyjne jak i ogólna koncepcja nagrobka wydają się być zbliżone, jednak są to elementy na tyle uniwersalne, że budowanie tylko na tej podstawie teorii wydaje się być nadużyciem. Natomiast gdyby udało się odnaleźć ów „abriz”, rysunek, według którego Marcin Krystian miał budować mauzoleum Szymona być może analogie stały by się wyraźniejsze. Tym bardziej, że kontrakt wyraźnie wymienia kolumny, nieistniejące $\mathrm{w}$ dzisiejszym mauzoleum, za to obecne w krośnieńskim nagrobku Firlejowej. Jak na razie jednak poszukiwania nie dały rezultatu.

$\mathrm{Z}$ powyższych wywodów wynikają jednak pewne stwierdzenia ${ }^{39}$.

Po pierwsze rzeźba Szymona jest na pewno starsza, niż do tej pory było uważane. Prawdopodobnie można ją wiązać $\mathrm{z}$ warsztatem Ticino, jednak dokładna datacja nie jest obecnie możliwa. Być może istnieją jeszcze jakieś archiwalia, które pomogą ustalić moment powstania figury, na pewno jednak powstała najpóźniej z początkiem wieku XVII, a być może wcześniej. Tym bardziej, że przy przebudowie kościoła ok. 1600 roku, zapewne zmieniono wystrój, niewykluczone jest jednak wykorzystanie elementów z poprzedniego kościoła.

Po drugie obecny ołtarz jest co najmniej czwartym z kolei, na ile jest on powtórzeniem pierwotnych koncepcji nie wiadomo, być może jednak stanowi przetworzenie wyglądu mauzoleum z początków XVII wieku.

${ }^{39}$ Tym samym informacje zawarte w przypisie 18 tracą aktualność. 


\section{Aneks}

Kontrakt zawarty dnia 3 października 16662 r. z Marcinem Krystianem, majstrem kamieniarskim, dotyczący budowy ołtarza (mauzoleum) błog. Szymona z Lipnicy w kościele OO. Bernardynów w Krakowie.

In nomine Domini, Amen.

Actum in Conventu Calvariensi 1662 die 3 - tia Octobris, in praesentia ARPatris Antoni Stefanowicz, Prov. Poloniae Ministri Provincialis et Patris Hyacinthi Butkwicz, Diffinitoris Provinciae Actualis. Stało sie postanowienie między Panem Andrzejem Jasieńskim, Miesczaninem Kazmirskim, a Sindikiem Klasztoru Krakowskiego Oyców Bernardynów na Stradomiu z iedney strony, y Panem Marcinem Krystianem roboty kamienney, marmurowey magistrem $\mathrm{z}$ drugiej strony, względem wystawienia nagrobku marmurowego Błogosławionemu Szymonowi z Lipnice do kościoła na Stradom. w ten sposób, iż Pan Marcin bedzie powinien zrobić y wystawić nagrobek marmurowy wszystek wedle podpisanego abrizu, gdzie w Tumbie ma bydz persona Blogoslawionego Szymona z marmuru wiśniowego koloru, ktory iest na Stradomiu, wypolerowawszy co potrzeba, to co iest zepsowanego, columny maia bydz na cztery łokcie bez ćwierci marmurowe, capitele zas pstrego marmuru, albo alabastrowe, ieżeli bedzie mogło bydz, pyramydy czarnego marmuru, ozdobione drobno dla wydatnosci alabastrem, szpregle czerwonego marmuru, structura wszystkiey roboty nagrobku marmurowego wzwysz rachuiąc y $\mathrm{z}$ Tumbą na dziesięc łokci, za ktorą robotę Pan Syndyk powinien bedzie oddac Panu Marcinowi pieniędzy złotych Polskich dziewięćset y legumina te: masła fasek trzy, sera kop trzy, miesa połci trzy, grochu ćwiertnia jedne, krup ieczmiennych ćwiertnią iedne, tatarczanych ćwiertnią iedne, mąki pszenney y żytney ćwiertni, wymawia sobie przytym Pan Marcin powóz na sprowadzenie tych marmorów od góry takie co potrzeba do postanowienia nagrobku, żelaza, ołowiu, wapna, cegły y pomocnika a tę robotę ma wystawić we trzech leciech, a pieniędzy wybierać bedzie na raty, tak iednak zeby na ostatnią ratę zostawało dwieście złotych, które zaraz po wystawieniu tey roboty y collocatiey na mieyscu powinien bedzie Pan Syndik oddac do rak Panu Marcinowi. Co sobie obiedwie stronie przyrzekaią dochować, a na utwierdzenie tego kontraktu pieczęć klasztoru wykładaią y rękami się własnemi podpisuią przy swiatkach wzwysz mianowanych. Działo się to roku, miesiąca, dnia ut supra.

Martin Krystian tim [...]

(własnoręczny podpis wykonawcy nagrobka)

poniżej

Odebral ad rationem tey roboty. Figuram [... nieczytelne] Anno 1662 die 20 octobris

podpis Martin Krystian tim [...]

poniżej

Odebrat Martin ustaloney ad rationem legumini: faskę iedne masta, y poleć ieden stoniny, y korzec krup ieczmiennych krakowskich

podpis nieczytelny

Rkps Archiw. Prow. Bernardynów w Krakowie sygn. I-e-7 Akta dotyczące błog. Szymona z Lipnicy i jego kultu 1486-1949, s. 39-42. 
Ad Septimum. Interrogatus produxit chartam tenoris sequen. Nobilis Ioannes Radziechowski incola Palatinatus Crac vir Sexagenarius sub fide honore conscientia et iuramento formali recognosco et attestor coram Magnificis et Adm Rdis ad actum inquisitionis circa Beatum Simonem de Lipnica destinatis in haec verba. Adryan Grymza wielki Filozof w Akademiey Krakowskiey uczył się i ten został iurystą wielkim in iure polonico miał specialem devotionem do Oycow Bernardynow; miał tez istam pietatem ze z Heretykami rad się zmawiał ¿ bo alias był multae lectionis pisma Swiętego y Doktorow Swiętych. Zaczym kilka heretykow mianowicie Ambrozego Stankara \& syna Franciska Stankara heretyka ministra wielkiego pismem Swiętym będąc $\mathrm{z}$ niem in conversatione w Kancellaryey Grodskiej Krakowskiej przywiodł do tego ze publice rewokował y katolikiem dobrym został. Potym y Chrystofa Pawłowskiego Szlachcica z Oyca y Matki ariana wielkiego; et solide doctum in Philosophicis, cudzych kraiew dobrze wiadomego i iuristę wielkiego sprowadzaiąc nan wielkich Theologow Dominikanow Bernardynow y Akademikow ratiobus et persuabus politicis przywiodł ze Aryanismu odstapił, rewokował, publice sie okrzcił y Sakramenta Swięte przyiął y potym iurystą będąc w Lublinie na aktach publicznych często u Oycow Bernardynow Dominikanow disputował y Theses opugnował y katolikiem dobrym był. Tenze Adryan Grymza miał wielka pietatem w tym ze Iałmuzny wielkie dawał tak Zakonnikom iako y wszelakim ubogim ze zadnego mędykantem $\mathrm{z}$ domu swego bez iałmuzny nie puscil, y ludziom ubogim w prawie darmo shuzył. Tenze Grymza Adryan circa Annum 1607. gdy barzo zachorzał, tak yz de vita sua perielitabatur $i$ o pułnocy ukazał mu sie Fr Simon de Lipnica Bernardyn ktorego osobe z Kamienia wyrzezana na Stradomiu w Kościele u Oycow Bernardvnow widvwal ¿ ktoremu on adoratią przystoyną uczynił y votum, tak yz zaraz potey apparitiey convalvit. Swiecę kazał zaswiecic y votum solenne do grobu tego S. Symona uczynił ¿ zaraz ozdrowiawszy poszedł do Koscioła Oycow Bernardynow mularza stargowal ktoremu szescset zlotvch dal za marmurv $v$ vnsze sztuki y potrzebv rzezane; a maiąc ze mną Radziechowskim magnum familiaritatem, gdym go pytal kto postawil nagrobek B Simoni de Lipnice, tedy formalia verba protulit Anno. 1609. prawdziwie przyznal y pod przysięgą powiedzial. Ukazal mi się S. Szymon z Lipnice y obiecal mi zdrowie bom iuz od Doktorow odstąpiony byl: ia natvchmiast ozdrowial v in gratitudinem huic Sancto Patrono meo, mausoleum extruxi. Zył potym ten to Grymza lat kilkanascie, y miał specialem devotionem do grobu tego S. ktory Swięty lezy u Oycow Bernardynow y onych szanował y obserwował przed ynszemi zakonnikami, tego dokładayac, ze tylko ten zakon S. Franciszka iuxta regulam zyią.

Archiwum Prow. Bernardynów w Krakowie rkp. sygn. I-e-2: Akta dotyczące procesu beatyfikacyjnego Błog. Szymona z Lipnicy, 1637 rok, s. 75-76. 